\title{
Effects of smoking cessation on $\beta$-cell function, insulin sensitivity, body weight, and appetite
}

\author{
Marietta Stadler 1,2,3, Larissa Tomann², Angela Storka4, Michael Wolzt ${ }^{4}$, \\ Slobodan Peric ${ }^{2}$, Christian Bieglmayer ${ }^{5}$, Giovanni Pacini ${ }^{6}$, Suzanne L Dickson? \\ Helmut Brath ${ }^{8}$, Paul Bech ${ }^{9}$, Rudolf Prager ${ }^{1,2}$ and Márta Korbonits ${ }^{10}$ \\ ${ }^{1} 3$ rd Medical Department of Metabolic Diseases and Nephrology, Hietzing Hospital, Vienna, Austria, \\ ${ }^{2}$ Karl Landsteiner Institute of Metabolic Diseases and Nephrology, Vienna, Austria, ${ }^{3}$ Diabetes Research Group, \\ King's College London, Weston Education Centre, Denmark Hill Campus, 10 Cutcombe Road, London SE5 9RJ, UK, \\ ${ }^{4}$ Department of Clinical Pharmacology, Medical University Vienna, Vienna, Austria, ${ }^{5}$ Institute for Medical and \\ Chemical Laboratory Diagnostics, Medical University Vienna, Vienna, Austria, ${ }^{6}$ Metabolic Unit, Institute of \\ Biomedical Engineering, National Research Council (ISIB-CNR), Padova, Italy, ${ }^{7}$ Institute of Neuroscience and \\ Physiology, The Sahlgrenska Academy, University of Gothenburg, Gothenburg, Sweden, ${ }^{8}$ Diabetes Outpatient \\ Clinic, Health Care Centre South, Vienna, Austria, ${ }^{9}$ Division of Diabetes, Endocrinology and Metabolism, Section of \\ Investigative Medicine, Imperial College London, Hammersmith Hospital, London, UK and ${ }^{10}$ Department of \\ Endocrinology, Barts and the London School of Medicine, William Harvey Research Institute, Queen Mary University \\ of London, London, UK
}

\author{
Correspondence \\ should be addressed \\ to M Stadler \\ Email \\ marietta.stadler@kcl.ac.uk
}

\begin{abstract}
Objective: To stop smoking is commonly associated with significant weight gain, but the mechanisms for this are poorly understood. We assessed the effects of smoking cessation on body weight, insulin sensitivity, $\beta$-cell function, and appetite. Subjects and methods: Twenty-seven long-term smokers ( $n=27$; nine females $/ 18$ males, $28 \pm 1$ years, $22.9 \pm 0.6 \mathrm{~kg} / \mathrm{m}^{2}$ ) attending an ambulatory smoking cessation program in a community hospital in Vienna, Austria were examined at baseline (Visit A; still smoking) and after a minimum of 3 months of smoking abstinence (Visit $B ; n=14$ ); relapsed smokers were not followed up. Participants underwent 3-h oral glucose tolerance tests and body composition measurements at each study visit. Fasting (QUICKI) and dynamic (oral glucose insulin sensitivity (OGIS)) insulin sensitivity and $\beta$-cell secretion (insulinogenic index 140 (IGI40)) were calculated. Food intake was quantified with a free choice buffet. Fasting plasma concentrations of neuropeptide-Y (NPY), peptide-YY (PYY), glucagon-like peptide 1 (GLP1), leptin, ghrelin, and visfatin were measured. Results: After $>3$ months' smoking abstinence, body weight, and fat mass were increased $(+4$ and $+22 \%$ respectively, $P<0.05$ ) and fasting insulin sensitivity deteriorated (QUICKI: post, $0.37 \pm 0.02$ vs baseline, $0.41 \pm 0.2 ; P<0.05$ ), while OGIS remained unchanged throughout. IGI40 increased by $31 \%$ after $>3$ months' smoking abstinence $(P<0.01)$. Carbohydrate ingestion increased after stopping smoking $(P<0.05)$. NPY fasting levels were increased after $>3$ months $(P<0.05)$, PYY, GLP1, leptin, ghrelin, and visfatin were unchanged.

Conclusion: Smoking cessation is associated with transient metabolic changes including increased $\beta$-cell secretion in response to glucose and fasting insulin resistance. These alterations may be associated with or contribute to the body weight gain after smoking cessation.
\end{abstract}

\section{Introduction}

Cigarette smoking is the leading preventable cause of death and disability worldwide (WHO 2011). It is known to be associated with increased risk of atherosclerosis, leading to myocardial infarction, stroke and intermittent claudication, and with increased risk of cancer $(1,2)$. Furthermore, smoking increases the risk of type 2 (c) 2014 European Society of Endocrinology Printed in Great Britain
Published by Bioscientifica Ltd. 
diabetes (3). Although these facts are commonly known and in spite of numerous public health campaigns directed at smoking cessation, a large percentage of people worldwide continue smoking. The failure to quit can largely be attributed to the addictive properties of nicotine, but an added disincentive is the realistic fear of weight gain after smoking cessation (4). It has been observed that the weight gain is particularly marked amongst people who have recently quit smoking $(5,6)$.

The mechanisms underlying the effects of smoking cessation on body weight are poorly understood. Previous studies have suggested a reduction in basal energy expenditure as well as increased caloric intake after stopping smoking $(7,8)$ and it is known from previous studies that smokers are more insulin resistant than nonsmokers (9). However, it has not yet been investigated whether $\beta$-cell function is influenced by cigarette smoking, or whether stopping smoking alters insulin sensitivity and $\beta$-cell function in ways that might relate to changes in appetite and body weight, or whether cigarette smoking and its cessation affects peripheral appetite regulating feedback signals.

We report here that the effects of smoking cessation on body weight and composition, insulin sensitivity, $\beta$-cell function, and plasma levels of peripheral appetite regulating hormones in a prospective study of smokers participating in a smoking cessation program before and after a minimum of 3 months of cigarette abstinence.

\section{Subjects and methods}

\section{Participants}

Long-term smokers (nine females and 18 males) who had been smoking at least the equivalent of five pack-years (calculated as number of cigarette packs smoked per day multiplied by the years of smoking duration) and who were attempting to quit smoking participated in this study. They were prescreened for confirmation of good health and the absence of any regular drug intake affecting insulin sensitivity, blood pressure, circulating lipids, or glucose. Exclusion criteria included elevated systolic and diastolic blood pressure ( $>140$ systolic/ $>90$ diastolic $(\mathrm{mmHg}))$ in one or more of three measurements, pronounced hyperlipidemia (fasting circulating cholesterol $>200 \mathrm{mg} / \mathrm{dl}$ and/or triacylglycerol $>180 \mathrm{mg} / \mathrm{dl}$ ), diabetes mellitus (fasting and $2 \mathrm{~h}$ glucose $\geq 126$ and/or $\geq 200 \mathrm{mg} / \mathrm{dl}$, respectively, during an oral glucose tolerance test (OGTT)), and the presence of other chronic diseases, such as overt cardiovascular disease (based on the clinical history and resting electrocardiogram). Local Ethics Committee approval was obtained and the participants signed written informed consent.

\section{Smoking cessation protocol}

The baseline study was performed while the participants were still smokers. On the first appointment, nicotine dependence (Fagerström test of nicotine dependence (10)), expiratory carbon monoxide (CO, p.p.m.), and pack-years were assessed. Participants received standardized advice regarding well-balanced diet and regular physical exercise in order to avoid weight gain when quitting smoking. After the initial counseling, participants agreed on a defined calendar day when they would finally quit smoking ('day X') and they would aim to reduce cigarette consumption gradually until that day. Participants were contacted via telephone 2 weeks, 1 and 2 months after 'day $\mathrm{X}^{\prime}$ and were offered further appointments for counseling, if desired. Depending on individual smoking behavior and the individual's preference, nicotine withdrawal therapy via various routes ('Nicorette' chewing gum, transdermal patch, sublingual tablet, and inhaler) was offered, but tapered off again after a maximum of 2 months in order that the participants were nicotine free for at least 1 month before the first metabolic reassessment. After a minimum of 3 months of successful smoking cessation (Visit B), the participants were reevaluated using the same tests as at the baseline study day. The self-reported nonsmoking status was ascertained with cotinine measurements from the urine (i.e. cotinine must be undetectable) and $\mathrm{CO}$ measurements (CO below 7 p.p.m.) at the Visits B. Participants who started smoking again were not restudied after resuming. We invited those participants who were still nonsmokers after more than 6 months smoking cessation for a third metabolic assessment identical to the previous visits, but as this group was small $(n=8)$ we elected not to include these data to this report; for completeness, they are included as a supplement (Supplementary Figure 1, see section on supplementary data given at the end of this article and Supplementary Table 1).

\section{Metabolic assessment}

The protocol for the baseline (Visit A) and the $>3$ months smoking abstinence (Visit B) study visits was identical. Both study visits comprised body composition measurements, a 3-h frequently sampled OGTT (11) and quantification of appetite immediately after the OGTT by 
means of a free choice buffet (12). Women were studied during the follicular phase of their menstrual cycle (i.e. within 10 days of the onset of their menstrual period), given the previously observed differences in appetite and appetite-regulating hormones between the luteal and follicular phases of the menstrual cycle $(13,14)$.

After an overnight fast, a catheter was inserted into an antecubital vein for blood sampling. Body composition (fat, water, and lean body mass) was assessed applying bioimpedance analysis (BIA, Fa. Akern, Florence, Italy). Expiratory CO concentration (p.p.m.) was measured using CO detector (Mini Smokerlyser, Bedfont Instruments Ltd., Upchurch, UK). A concentration of $\mathrm{CO}<7$ p.p.m. was defined as normal (15). In addition, cotinine was measured in the spot urine to assure nonsmoking status at Visit B (Mashan Diagnostika, Reinbek, Germany).

Oral glucose tolerance test $>$ Participants were asked to drink a watery solution of 75 g glucose (Glukodrink, Roche Diagnostics) within $5 \mathrm{~min}$ and a 3-h OGTT was carried out. Blood samples were taken at fasting and at 10, 20, 30, 40, $60,90,120,150$ and $180 \mathrm{~min}$ of the OGTT (11). All samples were immediately centrifuged $\left(4{ }^{\circ} \mathrm{C}, 4000\right.$ r.p.m., $10 \mathrm{~min}$ ) and the supernatant plasma and serum were stored at $-70{ }^{\circ} \mathrm{C}$ until further analysis.

Free choice buffet $>$ After the OGTT, participants were offered a free choice buffet, consisting of bread rolls, ham, cheese, butter, milk, yoghurt, orange juice, tea, coffee, water, and chocolate. The type and the exact quantity of the food consumed was weighed and registered in order to measure total caloric intake: fat, carbohydrate, and protein consumption (12).

\section{Laboratory analyses}

HbA1c, plasma glucose, and serum concentrations of creatinine, liver transaminases, triglycerides, and total-, LDL-, and HDL-cholesterol were measured using routine laboratory methods (www.kimcl.at).

Plasma insulin and C-peptide concentrations were measured by commercially available RIAs (Pharmacia and Cis (Gif-Sur-Yvette, France) respectively) (16). Fasting levels of appetite-regulating hormones were measured using commercially available kits (ghrelin: RIA (intra-assay coefficient of variation (CV) 7.4\%, inter-assay CV 12\%), Phoenix Pharmaceuticals, Inc., Belmont, CA, USA; leptin: RIA (intra-assay $\mathrm{CV}<5 \%$, inter-assay $\mathrm{CV}<9 \%$ ), R\&D, Minneapolis, MN, USA; neuropeptide-Y (NPY; intra-assay CV 6.4\%, inter-assay CV 10.1\%), and visfatin (intra-assay
CV 5.8\%, inter-assay CV 11.5\%), EIA, Phoenix Pharmaceuticals, Inc.) $(17,18,19,20)$ and in house RIA (glucagonlike peptide 1 (GLP1); the intra and inter-assay CVs are both $<10 \%$. (21), peptide-YY (PYY); inter-assay CV <15\%, intra-assay $\mathrm{CV}<9 \%$. (22)).

\section{Calculations and statistical analyses}

$\beta$-cell secretion and insulin sensitivity $\downarrow \beta$-cell secretion was evaluated as the $\mathrm{C}$-peptide response to the glycemic stimulus using the insulinogenic index (IGI), an OGTTbased measure which has been widely used (23). The IGI40 is calculated as the ratio between C-peptide area under the curve (AUC) and glucose AUC in the time interval from 0 to $40 \mathrm{~min}$ of the OGTT (23). The choice of $40 \mathrm{~min}$ derives from the fact that at $40 \mathrm{~min}$ the $\mathrm{C}$-peptide concentration reached its peak value (23).

Insulin sensitivity during OGTT was assessed by the oral glucose insulin sensitivity (OGIS) index, which takes into account known relationships between glucose disappearance and insulin (24). Fasting insulin sensitivity was calculated using QUICKI (25).

Statistical analysis $>$ Sample size was calculated using the programme 'StatMate' (GraphPad, La Jolla, CA, USA). We assumed 0.05 as two-tailed $\alpha$ and a power of $95 \%$, and this was based on insulin sensitivity measured with OGIS as outcome parameter. The power calculation suggested studying at least ten participants. We assumed a dropout rate of $50-60 \%$ based on previous studies on people who stopped smoking (15) and planned to initially enrol 27 participants. Comparisons before and after smoking cessation were performed using the paired two-sided Student's $t$-test and subjects were compared against their own baseline. For unpaired data comparison, we used twosided Student's $t$-test (SPSS, 19.0). Data are shown as mean \pm s.E.M. Differences were considered statistically significant when $P<0.05$.

\section{Results}

Anthropometric characteristics, details regarding nicotine dependency and previous cigarette consumption, body composition, and routine laboratory measurements at baseline (Visit A) and after a minimum of 3 months' smoking cessation (Visit B) are presented in Table 1. Routine laboratory parameters were not altered by smoking cessation (Table 1).

Of the initially included 27 participants, 14 were successful at stopping smoking for a minimum of 
Table 1 Anthropometric and laboratory measurements, as well as body composition and food intake at the free choice buffet, in the participants at baseline (Visit A) and after a minimum of 3 months (Visit B) of smoking cessation. Data are presented as mean \pm S.E.M. Differences between Visit B and the baseline visit (Visit A) were assessed with paired Student's $t$-tests.

\begin{tabular}{|c|c|c|c|}
\hline & Visit A & Visit B & \\
\hline & Smoking/baseline $(n=27)$ & $>3$ months nonsmoking $(n=14)$ & $P$ value (paired $t$-tests) \\
\hline \multicolumn{4}{|l|}{ Anthropometry } \\
\hline Age & $28.9 \pm 1.2$ & $27.0 \pm 1.3$ & NA \\
\hline$n$ in the study $(\mathrm{f} / \mathrm{m})$ & $27(9 / 18)$ & $14(5 / 9)$ & \\
\hline BMI $\left(\mathrm{kg} / \mathrm{m}^{2}\right)$ & $22.9 \pm 0.6$ & $23.4 \pm 0.8$ & $<0.01$ \\
\hline Body weight (kg) & $72.4 \pm 2.7$ & $73.8 \pm 4.5$ & $<0.01$ \\
\hline Lean body mass $(\%)$ & $80.1 \pm 1.6$ & $76.1 \pm 2.6$ & $<0.05$ \\
\hline Fat mass $(\%)$ & $19.9 \pm 1.6$ & $21.4 \pm 2.1$ & $<0.05$ \\
\hline Blood pressure $(\mathrm{mmHg})$ & $126 \pm 2 / 69 \pm 2$ & $127 \pm 3 / 72 \pm 3$ & NS \\
\hline \multicolumn{4}{|l|}{ Smoking status } \\
\hline Pack-years (at baseline) & $12.7 \pm 1.7$ & & \\
\hline Fagerström score (at baseline) & $4.4 \pm 0.4$ & & \\
\hline Days smoke-free & - & $132 \pm 16$ & \\
\hline Days nicotine replacement & - & $66 \pm 11$ & \\
\hline \multicolumn{4}{|l|}{ Laboratory measurements } \\
\hline $\mathrm{LDL}(\mathrm{mg} / \mathrm{dl})$ & $108 \pm 7$ & $99 \pm 7$ & NS \\
\hline $\mathrm{HDL}(\mathrm{mg} / \mathrm{dl})$ & $72 \pm 3$ & $72 \pm 5$ & NS \\
\hline Total cholesterol (mg/dl) & $184 \pm 8$ & $184 \pm 11$ & NS \\
\hline Serum creatinine (mg/dl) & $0.96 \pm 0.02$ & $1.01 \pm 0.04$ & NS \\
\hline Triglycerides (mg/dl) & $87 \pm 8$ & $105 \pm 18$ & NS \\
\hline GOT (U/I) & $21 \pm 2$ & $21 \pm 2$ & NS \\
\hline GPT (U/l) & $20 \pm 3$ & $23 \pm 4$ & $<0.1$ \\
\hline GGT (U/I) & $21 \pm 3$ & $26 \pm 4$ & $<0.05$ \\
\hline $\mathrm{HbA1c}$ & $4.9 \pm 0.1$ & $5.0 \pm 0.1$ & NS \\
\hline Glucose (fasting plasma, mg/dl) & $85 \pm 2$ & $84 \pm 2$ & NS \\
\hline Insulin fasting serum $(\mu \mathrm{U} / \mathrm{ml})$ & $9.8 \pm 0.8$ & $23.0 \pm 3.4$ & $<0.05$ \\
\hline C-peptide fasting serum ( $\mathrm{ng} / \mathrm{ml})$ & $2.0 \pm 0.2$ & $3.9 \pm 0.4$ & $<0.05$ \\
\hline Leptin fasting plasma $(\mathrm{ng} / \mathrm{ml})$ & $2.1 \pm 0.3$ & $3.0 \pm 0.71$ & NS \\
\hline GLP1 fasting (pmol/l) & $45 \pm 5.3$ & $49.4 \pm 2.8$ & NS \\
\hline Ghrelin fasting (ng/ml) & $21.3 \pm 2.3$ & $21.0 \pm 6.5$ & NS \\
\hline Visfatin fasting (ng/ml) & $9.5 \pm 1.2$ & $10.3 \pm 0.7$ & NS \\
\hline PYY fasting (pmol/l) & $23 \pm 3.0$ & $32.4 \pm 6.4$ & NS \\
\hline NPY fasting (ng/ml) & $0.33 \pm 0.05$ & $0.41 \pm 0.03$ & $<0.05$ \\
\hline \multicolumn{4}{|l|}{ Food intake free choice buffet } \\
\hline Kcal total & $857 \pm 93$ & $1073 \pm 103$ & NS \\
\hline Kcal carbohydrates & $374 \pm 36$ & $500 \pm 39$ & $<0.05$ \\
\hline Kcal fat & $314 \pm 41$ & $365 \pm 51$ & NS \\
\hline Kcal protein & $170 \pm 19$ & $208 \pm 23$ & NS \\
\hline \multicolumn{4}{|l|}{ Insulin sensitivity and $\beta$-cell function } \\
\hline QUICKI & $0.41 \pm 0.02$ & $0.31 \pm 0.01$ & $<0.02$ \\
\hline OGIS & $530 \pm 17$ & $549 \pm 36$ & NS \\
\hline Insulinogenic index $40 \mathrm{~min}$ & $0.30 \pm 0.11$ & $0.39 \pm 0.11$ & $<0.01$ \\
\hline
\end{tabular}

GOT, glutamic oxaloacetic transaminase; GPT, glutamate pyruvate transaminase; GGT, gamma glutamyl transpeptidase; GLP1, glucagon-like peptide 1; PYY, peptide-YY; NPY, neuropeptide-Y.

3 months (132 \pm 16 days) and were without nicotine replacement for $66 \pm 13$ days.

\section{Body weight and composition}

After $>3$ months nonsmoking and compared with baseline, body weight, and fat mass increased by 4 and $22 \%$ respectively, while the percentage of lean body mass decreased by $5 \%$ after $>3$ months (Table 1 ).

\section{Free choice buffet and appetite regulating hormones}

Carbohydrate ingestion was significantly increased after $>3$ months smoking cessation when compared with baseline (Table $1 ; P<0.05$ ). The overall calorie intake and calories from fat and protein were not different (Table 1). The fasting plasma concentrations of the appetiteregulating hormones GLP1, ghrelin, visfatin, and PYY were not significantly different after smoking cessation 
compared with baseline. Fasting concentrations of the orexigenic peptide NPY were increased at Visit B $(P<0.05$; Table 1). After $>3$ months nonsmoking, fasting insulin and C-peptide levels were approximately twofold higher than at baseline (Table 1).

\section{Insulin sensitivity and $\beta$-cell secretion}

Plasma insulin, C-peptide, and glucose levels during the 3-h OGTT are presented in Fig. 1A, B and C. Participants who had stopped smoking showed significant fasting hyperinsulinemia (Fig. 1A) and fasting insulin resistance (Table 1) after $>3$ months' smoking cessation (Visit B). The dynamic measure of insulin sensitivity, OGIS, remained unchanged throughout the study (Table 1). $\beta$-cell secretion, as measured with the IGI40, increased by $31 \%$ at Visit B (baseline, $0.30 \pm 0.11$ vs 3 months, $0.39 \pm$ $0.11, P<0.01$; Table 1 ).

\section{Discussion}

In our study, smoking cessation was associated with significant body weight gain. Furthermore, we found

Visit A (smoking)

Visit B (>3 months nonsmoking)

A

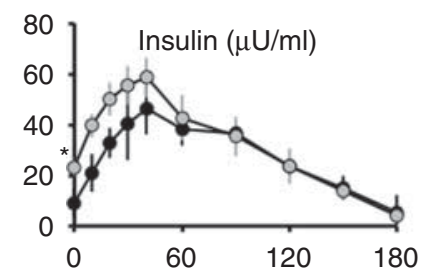

C

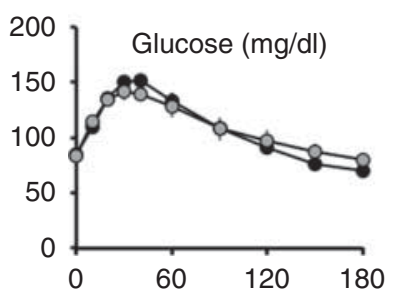

Figure 1

Plasma concentrations of insulin (A), C-peptide (B), and glucose (C) during the 3 -h oral glucose tolerance test (OGTT); in the participants at baseline (black, Visit $A, n=14$ ), after a minimum of 3 months' (gray, Visit $B, n=14$ ) smoking cessation. Data are presented as mean \pm s.E.M. Differences between Visit $B$ and $C$ and the baseline visit (Visit $A$ ) were assessed with paired Student's $t$-tests (in A, B and C only fasting measurements were compared). ${ }^{*} P<0.05$. that several aspects of glucose metabolism changed in the early phase of stopping smoking: insulin secretion, as reflected by fasting hyperinsulinemia and $\beta$-cell secretion in response to oral glucose, as well as dietary intake of carbohydrate, increased after 3 months of smoking cessation.

\section{Body weight and composition after smoking cessation}

An inverse relationship between cigarette smoking and body weight has been observed in rodents and humans (26). Knowing the health hazards of smoking, smokers often cite the fear of weight gain after smoking cessation as a reason for their failure to quit (4). Although smokers have a lower BMI compared with nonsmokers, they have more metabolically adverse fat distribution with higher central adiposity (27). Nicotine stimulates lipolysis without increasing oxidation of fat, leading to increased free fatty acid concentrations (28), which may be one of the mechanisms rendering smokers more insulin resistant than nonsmokers (29). Heavy smokers who stopped smoking and maintained an isocaloric diet did not have a rebound tendency to synthesize or store more fat (28), but when they had ad libitum food intake lipid de novo synthesis increased in proportion to their increased caloric intake (30). Our data confirm that smoking cessation leads to a clinically relevant increase in body weight and fat mass. Therefore, tackling weight gain remains an important clinical issue as part of improving the overall health outcome of individuals who successfully stop smoking.

\section{Insulin sensitivity and secretion after smoking cessation}

Chronic smokers exhibit slightly increased fasting plasma insulin concentrations (31), increased fasting plasma glucose concentration (32), and decreased insulin sensitivity compared with nonsmoking controls $(9,33)$. In our study, smoking cessation led to an initial (i.e. after 3 months) further deterioration in fasting insulin sensitivity (QUICKI) and fasting hyperinsulinemia, but no change in dynamic insulin sensitivity in the OGTT (OGIS). Two other studies have shown improvements in whole-body insulin sensitivity 1-2 and 8 weeks after stopping smoking respectively $(34,35)$. It is possible that an initial positive effect of smoking cessation on insulin sensitivity (maybe missed in our study on account of the protocol timing) is followed by the deterioration we observed at 3 months - by which time body weight gain was already significant. 
Nicotine may influence $\beta$-cell function directly or indirectly via the parasympathetic ganglia. Animal studies and in vitro experiments suggest that nicotine exposure results in functional impairment and loss of $\beta$ cells $(36,37,38)$. In rabbits, high concentrations of nicotine inhibit glucose-induced insulin secretion, while lower doses stimulated insulin secretion (39). At the time of metabolic reevaluation after smoking cessation, subjects had also stopped their nicotine replacement for $66 \pm 13$ days (minimum 24 days), confirmed by negative cotinine tests. It is therefore unlikely that insulin sensitivity or insulin secretion was still under the influence of nicotine.

Although caution should be exercised against the over-interpretation of preliminary data, we speculate that the increased insulin secretion observed could either be a 'rebound phenomenon' in response to the absence of nicotine action in the pancreas or, alternatively, a compensatory response to the transiently increased fasting insulin resistance. These findings of an increase in insulin secretion and insulin resistance after smoking cessation raise the obvious question as to whether treating insulin resistance (e.g. with metformin) could be beneficial in avoiding weight gain after quitting smoking. Randomized controlled studies would be required to investigate this.

\section{Appetite after smoking cessation}

Participants ate significantly more carbohydrates during the free choice buffet after 3 months of smoking cessation, corresponding to the transient increases of fasting insulin levels and $\beta$-cell secretion.

Studies on animal models (40) suggest that nicotine affects central appetite regulation, either by a direct effect (nicotine receptors have been found in the hypothalamus, particularly in the lateral hypothalamus which is believed to be involved in appetite regulation (41)) or indirectly (e.g. suppression of hypothalamic NPY concentrations (42), activation of pro-opiomelanocortin neurons (43)). Nicotine-treated rats eat less and gain less weight than placebo-treated animals, but weight gain catches up after nicotine cessation (44). It has been suggested that insulin (now known to cross the blood-brain-barrier (45)), as well as leptin, may influence food intake by acting as nonpeptide neurotransmitters $(46,47)$. In addition, neuroimaging studies have shown that smoking and food cues activate similar areas in the brain (left amygdala, bilateral orbitofrontal cortex, and striatum and insula) thought to respond to conditioned cues associated with natural and drug rewards (48). It would be tempting to relate the increased insulin, fasting insulin resistance, and insulin secretion in response to oral glucose with the increased appetite for carbohydrates in smoking cessation by suggesting that there could be a 'cerebral insulin resistance' to the satiety signal of insulin when the 'reward' previously gained by smoking is lacking. However, this is purely speculative and certainly cannot be answered with the study design at hand.

Fasting GLP1, leptin, ghrelin, visfatin, and PYY levels were unchanged after smoking cessation in our study, but fasting NPY levels were increased after 3 months. NPY is produced in the arcuate nucleus/infundibulum of the hypothalamus and also at peripheral sites such as the adrenal glands. In animal experiments, exogenous administration of NPY stimulates feeding $(49,50)$. The effects of nicotine treatment in rat experimental models of NPY peptide levels were conflicting, depending on the dosage and route of nicotine administration $(51,52)$. There are a number of possible explanations for our finding. Given that NPY may be released along with catecholamines by the activation of the sympathoadrenal system, plasma NPY may serve as an index of sympathoadrenal activity $(53,54)$. Cigarette smoking stimulates, whereas stopping smoking decreases the sympathetic nervous system activity $(55,56)$. Plasma catecholamines were not measured, but the heart rate and blood pressure were unchanged over the course of the study. Therefore, it seems unlikely that the increased NPY levels observed after smoking cessation are due to increased sympathetic activation. Another possibility for the change in NPY levels after smoking could be the increased carbohydrate intake (57). A third possibility, given that increased NPY plasma levels are found in insulin resistant states, such as type 2 diabetes, obesity, and hypertension $(58,59)$, is that NPY is increased as a consequence of increased insulin resistance observed in our study participants. Last, given that NPY is found to be produced in pancreatic $\beta$ cells and to inhibit insulin secretion in vitro $(60,61)$, it is conceivable that changes in NPY could reflect the alteration in $\beta$-cell function following smoking cessation. Further work will be needed to investigate this.

The increase in carbohydrate intake could be attributed to several factors. Nonsmokers and smokers who are not smoking seem to perceive the sweet taste as more pleasant than smokers (62). Carbohydrate ingestion was linked to central reward centers in behavioral experiments in people undergoing nicotine withdrawal (63). Further studies involving brain imaging will be needed to elucidate the link between carbohydrate ingestion and smoking cessation. 
Limitations $\downarrow$ A high proportion of participants started smoking again, as is unfortunately very common in smoking cessation $(15,64)$. This study was mainly focussed on the metabolic aspects of smoking cessation rather than the psychological, therefore we have not included any qualitative data in a structured manner on the reasons for failing to quit and were not able to provide data on these aspects.

Although it was intended to study our participants at exactly three months' smoking cessation, patient availability dictated that these time points stretched to an average of 132 days (each participant had abstained from smoking for a minimum of 3 months when restudied). We have performed a large number of statistical analyses in a rather small group of participants without correction for number of comparisons. Therefore, these preliminary findings would need to be confirmed in a further study in a larger group of people. The data from those who were still nonsmokers after $>6$ months are not presented in this report to avoid conclusions from a subgroup analysis which is rather small. We have amended these data as additional material as a matter of completeness.

Gender-related differences $>$ Although it has been shown that particularly women are concerned about gaining weight after smoking cessation (65), a longitudinal study observed a rather similar per year weight gain in men and women who stopped smoking (66), whereas another study reported that weight gain in women was $1 \mathrm{~kg}$ higher than in men (67). Owing to the small sample size, the parameters assessed in our study cannot be analysed for gender-related differences.

Nicotine replacement therapy $\downarrow$ Nicotine withdrawal therapy was used by all participants up to 2 months, therefore some participants have been cigarette free for 3 months but nicotine free for 1 month at Visit B (on average they were free of nicotine for 66 days). It is not possible to differentiate whether the effects observed were related to stopping cigarette exposure or to stopping nicotine exposure in a precise time-related manner. Given that people gain weight during smoking cessation already while on nicotine replacement, but do so at a slower rate (68) in comparison with placebo (69), the weight gain we would have observed could perhaps have been larger without nicotine replacement; however, not offering nicotine replacement could have resulted in an even bigger dropout rate.

In conclusion, our data demonstrate that smoking cessation is associated with transient metabolic changes at
3 months including increased fasting insulin resistance and $\beta$-cell secretion in response to glucose. These alterations may be associated with or contribute to the body weight gain after smoking cessation.

\section{Supplementary data}

This is linked to the online version of the paper at http://dx.doi.org/10.1530/ EJE-13-0590.

\section{Declaration of interest}

The authors declare that there is no conflict of interest that could be perceived as prejudicing the impartiality of the research reported.

\section{Funding}

At the European Congress of Endocrinology 2012, M Stadler was awarded a Young Investigator award for the abstract of this study. This study was in part supported by an UEMS-3E fellowship awarded to M Stadler and by a grant of the Austrian National Bank (project number 10787) awarded to $\mathrm{R}$ Prager and by European Commission Seventh Framework (FP7-KBBE2009-3-245009, Neurofast) to S L Dickson. Nicotine withdrawal therapy was provided by Pfizer free of charge.

\section{Author contribution statement}

M Stadler and L Tomann researched the data; C Bieglmayer, P Bech, A Storka, M Wolzt, and S Peric carried out laboratory analysis; G Pacini and M Stadler performed statistical analysis mathematical modelling; M Stadler wrote the manuscript; and G Pacini, S L Dickson, H Brath, R Prager, $M$ Korbonits, and $C$ Bieglmayer critically revised and edited the manuscript.

\section{References}

1 Benowitz NL. The role of nicotine in smoking-related cardiovascular disease. Preventive Medicine 199726 412-417. (doi:10.1006/pmed.1997. 0175)

2 Villablanca AC, McDonald JM \& Rutledge JC. Smoking and cardiovascular disease. Clinics in Chest Medicine 200021 159-172. (doi:10.1016/ S0272-5231(05)70015-0)

3 Willi C, Bodenmann P, Ghali WA, Faris PD \& Cornuz J. Active smoking and the risk of type 2 diabetes: a systematic review and meta-analysis. Journal of the American Medical Association 2007298 2654-2664. (doi:10.1001/jama.298.22.2654)

4 Pomerleau CS \& Kurth CL. Willingness of female smokers to tolerate postcessation weight gain. Journal of Substance Abuse 19968 371-378. (doi:10.1016/S0899-3289(96)90215-1)

5 Richmond RL, Kehoe L \& Webster IW. Weight change after smoking cessation in general practice. Medical Journal of Australia 1993158 821-822.

6 Caan B, Coates A, Schaefer C, Finkler L, Sternfeld B \& Corbett K. Women gain weight 1 year after smoking cessation while dietary intake temporarily increases. Journal of the American Dietetic Association 1996 96 1150-1155. (doi:10.1016/S0002-8223(96)00296-9)

7 Hofstetter A, Schutz Y, Jequier E \& Wahren J. Increased 24-hour energy expenditure in cigarette smokers. New England Journal of Medicine 1986 314 79-82. (doi:10.1056/NEJM198601093140204)

8 Moffatt RJ \& Owens SG. Cessation from cigarette smoking: changes in body weight, body composition, resting metabolism, and energy 
consumption. Metabolism 199140 465-470. (doi:10.1016/00260495(91)90225-L)

9 Facchini FS, Hollenbeck CB, Jeppesen J, Chen YD \& Reaven GM. Insulin resistance and cigarette smoking. Lancet 1992339 1128-1130. (doi:10.1016/0140-6736(92)90730-Q)

10 Fagerstrom KO \& Schneider NG. Measuring nicotine dependence: a review of the Fagerstrom Tolerance Questionnaire. Journal of Behavioral Medicine 198912 159-182. (doi:10.1007/BF00846549)

11 Stadler M, Anderwald C, Karer T, Tura A, Kastenbauer T, Auinger M, Bieglmayer C, Wagner O, Kronenberg F, Nowotny P et al. Increased plasma amylin in type 1 diabetic patients after kidney and pancreas transplantation: a sign of impaired $\beta$-cell function? Diabetes Care 2006 29 1031-1038. (doi:10.2337/dc05-1247)

12 Wren AM, Seal LJ, Cohen MA, Brynes AE, Frost GS, Murphy KG, Dhillo WS, Ghatei MA \& Bloom SR. Ghrelin enhances appetite and increases food intake in humans. Journal of Clinical Endocrinology and Metabolism 200186 5992. (doi:10.1210/jc.86.12.5992)

13 Brennan IM, Feltrin KL, Nair NS, Hausken T, Little TJ, Gentilcore D, Wishart JM, Jones KL, Horowitz M \& Feinle-Bisset C. Effects of the phases of the menstrual cycle on gastric emptying, glycemia, plasma GLP-1 and insulin, and energy intake in healthy lean women. American Journal of Physiology. Gastrointestinal and Liver Physiology 2009297 G602-G610. (doi:10.1152/ajpgi.00051.2009)

14 Reed SC, Levin FR \& Evans SM. Changes in mood, cognitive performance and appetite in the late luteal and follicular phases of the menstrual cycle in women with and without PMDD (premenstrual dysphoric disorder). Hormones and Behavior 200854 185-193. (doi:10.1016/j.yhbeh.2008.02.018)

15 Brath H, Lasar D, Buchhausl I, Kastenbauer T \& Binter E. Intensified smoking cessation for diabetic patients - preliminary results. Acta Medica Austriaca 199926 163-167.

16 Bischof MG, Bernroider E, Krssak M, Krebs M, Stingl H, Nowotny P, Yu C, Shulman GI, Waldhausl W \& Roden M. Hepatic glycogen metabolism in type 1 diabetes after long-term near normoglycemia. Diabetes 200251 49-54. (doi:10.2337/diabetes.51.1.49)

17 Stadler M, Krebs M, Promintzer M, Mandl M, Bischof MG, Nowotny P, Kaestenbauer T, Luger A, Prager R \& Anderwald C. Plasma obestatin is lower at fasting and not suppressed by insulin in insulin-resistant humans. American Journal of Physiology. Endocrinology and Metabolism 2007293 E1393-E1398. (doi:10.1152/ajpendo.00330.2007)

18 Stadler M, Storka A, Theuer EA, Krebs M, Vojtassakova E, Nowotny P, Pacini G, Kastenbauer T, Luger A, Prager R et al. Adipokines in type-1 diabetes after successful pancreas transplantation: normal visfatin and retinol-binding-protein-4, but increased total adiponectin fasting concentrations. Clinical Endocrinology 201072 763-769. (doi:10.1111/ j.1365-2265.2009.03709.x)

19 von der Goltz C, Koopmann A, Dinter C, Richter A, Rockenbach C, Grosshans M, Nakovics H, Wiedemann K, Mann K, Winterer G et al. Orexin and leptin are associated with nicotine craving: a link between smoking, appetite and reward. Psychoneuroendocrinology 2010 35 570-577. (doi:10.1016/j.psyneuen.2009.09.005)

20 Edholm T, Degerblad M, Gryback P, Hilsted L, Holst JJ, Jacobsson H, Efendic S, Schmidt PT \& Hellström PM. Differential incretin effects of GIP and GLP-1 on gastric emptying, appetite, and insulin-glucose homeostasis. Neurogastroenterology and Motility 201022 1191-1200. (doi:10.1111/j.1365-2982.2010.01554.x)

21 Kreymann B, Williams G, Ghatei MA \& Bloom SR. Glucagon-like peptide-1 7-36: a physiological incretin in man. Lancet 19872 1300-1304. (doi:10.1016/S0140-6736(87)91194-9)

22 Adrian TE, Savage AP, Sagor GR, Allen JM, Bacarese-Hamilton AJ, Tatemoto K, Polak JM \& Bloom SR. Effect of peptide YY on gastric, pancreatic, and biliary function in humans. Gastroenterology 198589 494-499.

23 Stadler M, Pacini G, Petrie J, Luger A \& Anderwald C. $\beta$ cell (dys)function in non-diabetic offspring of diabetic patients. Diabetologia 200952 2435-2444. (doi:10.1007/s00125-009-1520-7)
24 Mari A, Pacini G, Murphy E, Ludvik B \& Nolan JJ. A model-based method for assessing insulin sensitivity from the oral glucose tolerance test. Diabetes Care 200124 539-548. (doi:10.2337/ diacare.24.3.539)

25 Katz A, Nambi SS, Mather K, Baron AD, Follmann DA, Sullivan G \& Quon MJ. Quantitative insulin sensitivity check index: a simple, accurate method for assessing insulin sensitivity in humans. Journal of Clinical Endocrinology and Metabolism 200085 2402-2410. (doi:10.1210/ jc.85.7.2402)

26 Aubin HJ, Farley A, Lycett D, Lahmek P \& Aveyard P. Weight gain in smokers after quitting cigarettes: meta-analysis. BMJ 2012345 e4439. (doi:10.1136/bmj.e4439)

27 Canoy D, Wareham N, Luben R, Welch A, Bingham S, Day N \& Khaw KT. Cigarette smoking and fat distribution in 21,828 British men and women: a population-based study. Obesity Research 200513 1466-1475. (doi:10.1038/oby.2005.177)

28 Hellerstein MK, Benowitz NL, Neese RA, Schwartz JM, Hoh R, Jacob P III, Hsieh J \& Faix D. Effects of cigarette smoking and its cessation on lipid metabolism and energy expenditure in heavy smokers. Journal of Clinical Investigation 199493 265-272. (doi:10.1172/JCI116955)

29 Roden M, Price TB, Perseghin G, Petersen KF, Rothman DL, Cline GW \& Shulman GI. Mechanism of free fatty acid-induced insulin resistance in humans. Journal of Clinical Investigation 199697 2859-2865. (doi:10.1172/JCI118742)

30 Neese RA, Benowitz NL, Hoh R, Faix D, LaBua A, Pun K \& Hellerstein MK. Metabolic interactions between surplus dietary energy intake and cigarette smoking or its cessation. American Journal of Physiology 1994267 E1023-E1034.

31 Ronnemaa T, Ronnemaa EM, Puukka P, Pyorala K \& Laakso M. Smoking is independently associated with high plasma insulin levels in nondiabetic men. Diabetes Care 199619 1229-1232. (doi:10.2337/ diacare.19.11.1229)

32 Hanyu O, Yoshida J, Abe E, Hirayama S, Miyake K, Aizawa Y \& Miida T. High-sensitivity CRP reflects insulin resistance in smokers. Journal of Atherosclerosis and Thrombosis 200916 560-567. (doi:10.5551/jat.869)

33 Attvall S, Fowelin J, Lager I, Von Schenck H \& Smith U. Smoking induces insulin resistance - a potential link with the insulin resistance syndrome. Journal of Internal Medicine 1993233 327-332. (doi:10.1111/ j.1365-2796.1993.tb00680.x)

34 Eliasson B, Attvall S, Taskinen MR \& Smith U. Smoking cessation improves insulin sensitivity in healthy middle-aged men. European Journal of Clinical Investigation 199727 450-456. (doi:10.1046/ j.1365-2362.1997.1330680.x)

35 Bergman BC, Perreault L, Hunerdosse D, Kerege A, Playdon M, Samek AM \& Eckel RH. Novel and reversible mechanisms of smokinginduced insulin resistance in humans. Diabetes $2012613156-3166$. (doi:10.2337/db12-0418)

36 Bruin JE, Gerstein HC, Morrison KM \& Holloway AC. Increased pancreatic $\beta$-cell apoptosis following fetal and neonatal exposure to nicotine is mediated via the mitochondria. Toxicological Sciences 2008 103 362-370. (doi:10.1093/toxsci/kfn012)

37 Yoshikawa H, Hellstrom-Lindahl E \& Grill V. Evidence for functional nicotinic receptors on pancreatic $\beta$ cells. Metabolism $2005 \mathbf{5 4} 247-254$. (doi:10.1016/j.metabol.2004.08.020)

38 Woynillowicz AK, Raha S, Nicholson CJ \& Holloway AC. The effect of smoking cessation pharmacotherapies on pancreatic $\beta$ cell function. Toxicology and Applied Pharmacology 2012265 122-127. (doi:10.1016/ j.taap.2012.08.020)

39 Tjalve H \& Popov D. Effect of nicotine and nicotine metabolites on insulin secretion from rabbit pancreas pieces. Endocrinology 197392 1343-1348. (doi:10.1210/endo-92-5-1343)

40 Miyata G, Meguid MM, Varma M, Fetissov SO \& Kim HJ. Nicotine alters the usual reciprocity between meal size and meal number in female rat. Physiology \& Behavior 200174 169-176. (doi:10.1016/ S0031-9384(01)00540-6) 
41 Jo YH, Talmage DA \& Role LW. Nicotinic receptor-mediated effects on appetite and food intake. Journal of Neurobiology 200253 618-632. (doi:10.1002/neu.10147)

42 Chen H, Hansen MJ, Jones JE, Vlahos R, Bozinovski S, Anderson GP \& Morris MJ. Regulation of hypothalamic NPY by diet and smoking. Peptides 200728 384-389. (doi:10.1016/j.peptides.2006.07.034)

43 Mineur YS, Abizaid A, Rao Y, Salas R, DiLeone RJ, Gundisch D, Diano S, De Biasi M, Horvath TL, Gao XB et al. Nicotine decreases food intake through activation of POMC neurons. Science 2011332 1330-1332. (doi:10.1126/science.1201889)

44 Grebenstein PE, Thompson IE \& Rowland NE. The effects of extended intravenous nicotine administration on body weight and meal patterns in male Sprague-Dawley rats. Psychopharmacology 2013228 359-366. (doi:10.1007/s00213-013-3043-7)

45 Banks WA. The source of cerebral insulin. European Journal of Pharmacology 2004490 5-12. (doi:10.1016/j.ejphar.2004.02.040)

46 Baskin DG, Figlewicz LD, Seeley RJ, Woods SC, Porte D Jr \& Schwartz MW. Insulin and leptin: dual adiposity signals to the brain for the regulation of food intake and body weight. Brain Research 1999848 114-123. (doi:10.1016/S0006-8993(99)01974-5)

47 Morton GJ, Cummings DE, Baskin DG, Barsh GS \& Schwartz MW. Central nervous system control of food intake and body weight. Nature 2006443 289-295. (doi:10.1038/nature05026)

48 Tang DW, Fellows LK, Small DM \& Dagher A. Food and drug cues activate similar brain regions: a meta-analysis of functional MRI studies. Physiology \& Behavior 2012106 317-324. (doi:10.1016/ j.physbeh.2012.03.009)

49 Wahlestedt C \& Reis DJ. Neuropeptide Y-related peptides and their receptors - are the receptors potential therapeutic drug targets? Annual Review of Pharmacology and Toxicology 199333 309-352. (doi:10.1146/ annurev.pa.33.040193.001521)

50 Higuchi H, Yang HY \& Costa E. Age-related bidirectional changes in neuropeptide Y peptides in rat adrenal glands, brain, and blood. Journal of Neurochemistry 198850 1879-1886. (doi:10.1111/ j.1471-4159.1988.tb02492.x)

51 Frankish HM, Dryden S, Wang Q, Bing C, MacFarlane IA \& Williams G. Nicotine administration reduces neuropeptide $\mathrm{Y}$ and neuropeptide $\mathrm{Y}$ mRNA concentrations in the rat hypothalamus: NPY may mediate nicotine's effects on energy balance. Brain Research 1995694 139-146. (doi:10.1016/0006-8993(95)00834-D)

52 Li MD, Kane JK, Parker SL, McAllen K, Matta SG \& Sharp BM. Nicotine administration enhances NPY expression in the rat hypothalamus. Brain Research 2000867 157-164. (doi:10.1016/S00068993(00)02283-6)

53 Morris MJ, Russell AE, Kapoor V, Cain MD, Elliott JM, West MJ, Wing LM \& Chalmers JP. Increases in plasma neuropeptide Y concentrations during sympathetic activation in man. Journal of the Autonomic Nervous System 198617 143-149. (doi:10.1016/ 0165-1838(86)90089-5)

54 Harle P, Straub RH, Wiest R, Mayer A, Scholmerich J, Atzeni F, Carrabba M, Cutolo M \& Sarzi-Puttini P. Increase of sympathetic outflow measured by neuropeptide $\mathrm{Y}$ and decrease of the hypothalamic-pituitary-adrenal axis tone in patients with systemic lupus erythematosus and rheumatoid arthritis: another example of uncoupling of response systems. Annals of the Rheumatic Diseases 2006 65 51-56. (doi:10.1136/ard.2005.038059)

55 Grassi G, Seravalle G, Calhoun DA, Bolla GB, Giannattasio C, Marabini M, Del Bo A \& Mancia G. Mechanisms responsible for sympathetic activation by cigarette smoking in humans. Circulation 199490 248-253. (doi:10.1161/01.CIR.90.1.248)

56 Oncken CA, White WB, Cooney JL, Van Kirk JR, Ahluwalia JS \& Giacco S. Impact of smoking cessation on ambulatory blood pressure and heart rate in postmenopausal women. American Journal of Hypertension 200114 942-949. (doi:10.1016/S0895-7061(01)02147-1)

57 Scott EM, Greenwood JP, Vacca G, Stoker JB, Gilbey SG \& Mary DA. Carbohydrate ingestion, with transient endogenous insulinaemia, produces both sympathetic activation and vasodilatation in normal humans. Clinical Science 2002102 523-529. (doi:10.1042/CS20010239)

58 Baranowska B, Wolinska-Witort E, Wasilewska-Dziubinska E, Roguski K, Martynska L \& Chmielowska M. The role of neuropeptides in the disturbed control of appetite and hormone secretion in eating disorders. Neuroendocrinology Letters 200324 431-434.

59 Jaakkola U, Kakko T, Seppala H, Vainio-Jylha E, Vahlberg T, Raitakari OT \& Kallio J. The Leu7Pro polymorphism of the signal peptide of neuropeptide Y (NPY) gene is associated with increased levels of inflammatory markers preceding vascular complications in patients with type 2 diabetes. Microvascular Research 201080 433-439. (doi:10.1016/j.mvr.2010.07.010)

60 Whim MD. Pancreatic $\beta$ cells synthesize neuropeptide Y and can rapidly release peptide co-transmitters. PLOS ONE 20116 e19478. (doi:10.1371/journal.pone.0019478)

61 Schwetz TA, Ustione A \& Piston DW. Neuropeptide Y and somatostatin inhibit insulin secretion through different mechanisms. American Journal of Physiology. Endocrinology and Metabolism 2013304 E211-E221. (doi:10.1152/ajpendo.00374.2012)

62 Redington K. Taste differences between cigarette smokers and nonsmokers. Pharmacology, Biochemistry, and Behavior 198421 203-208. (doi:10.1016/0091-3057(84)90215-6)

63 Spring B, Pagoto S, McChargue D, Hedeker D \& Werth J. Altered reward value of carbohydrate snacks for female smokers withdrawn from nicotine. Pharmacology, Biochemistry, and Behavior 200376 351-360. (doi:10.1016/j.pbb.2003.08.008)

64 Stamford BA, Matter S, Fell RD \& Papanek P. Effects of smoking cessation on weight gain, metabolic rate, caloric consumption, and blood lipids. American Journal of Clinical Nutrition 1986 43 486-494.

65 Levine MD, Bush T, Magnusson B, Cheng Y \& Chen X. Smoking-related weight concerns and obesity: differences among normal weight, overweight, and obese smokers using a telephone tobacco quitline. Nicotine \& Tobacco Research 201315 1136-1140. (doi:10.1093/ntr/ nts226)

66 Travier N, Agudo A, May AM, Gonzalez C, Luan J, Wareham NJ, Bueno-de-Mesquita HB, van den Berg SW, Slimani N, Rinaldi S et al. Longitudinal changes in weight in relation to smoking cessation in participants of the EPIC-PANACEA study. Preventive Medicine 201254 183-192. (doi:10.1016/j.ypmed.2011.09.003)

67 Williamson DF, Madans J, Anda RF, Kleinman JC, Giovino GA \& Byers T. Smoking cessation and severity of weight gain in a national cohort. New England Journal of Medicine 1991324 739-745. (doi:10.1056/NEJM199103143241106)

68 Assali AR, Beigel Y, Schreibman R, Shafer Z \& Fainaru M. Weight gain and insulin resistance during nicotine replacement therapy. Clinical Cardiology 199922 357-360. (doi:10.1002/clc.4960220512)

69 Allen SS, Hatsukami D, Brintnell DM \& Bade T. Effect of nicotine replacement therapy on post-cessation weight gain and nutrient intake: a randomized controlled trial of postmenopausal female smokers. Addictive Behaviors 200530 1273-1280. (doi:10.1016/ j.addbeh.2005.01.003)

Received 18 July 2013

Revised version received 17 October 2013

Accepted 31 October 2013 